DOI: $10.14451 / 2.123 .7$

\title{
ПОНЯТИЕ «ОБХОД ЗАКОНА» В ГРАЖДАНСКОМ ПРАВЕ РОССИИ И США
}

\author{
(C) 2018 Попова Ирина Юрьевна \\ Адвокат Московской коллегии адвокатов «Бинецкий и партнеры» \\ г. Москва
}

В статье рассматриваются проблемы, связанные с обходом закона участниками экономических отношений. Автор предлагает собственное определение понятия «обход закона», классификацию случаев обхода закона, а также критерии для выявления случаев обхода закона на практике.

Автором обосновывается вывод о том, что несмотря на невозможность непосредственного использования американских правовых доктрин в российской судебной практике ввиду их противоречия основам российского гражданского права, такие доктрины могут стать основой для выработки отдельных мер законодательного и судебного характера, подобных тем, которые имеются в торговом и гражданском праве США.

Ключевые слова: сделка, обход закона, договор, притворные сделки, добросовестность, эстоппель.

Растущая конкуренция и постоянное усложнение правового регулирования современных экономических отношений все чаще приводят к тому, что их участники стремятся снизить свои издержки за счет сложных юридических схем, основанных на использовании сочетания диспозитивных правовых норм, пробелов и противоречий в законодательстве, возможностей его неоднозначного толкования для обхода существующих ограничений.

В связи с этим понятие «обход закона» приобретает все большее значение для современного гражданского права. На доктринальном уровне исследователи до настоящего времени не пришли к однозначным выводам о том, как именно следует оценивать действия, осуществляемые в обход закона, должен ли запрет на их совершение быть предусмотрен законом или он может выводиться из общих принципов права, какие именно последствия и в каких случаях должно вызывать совершений сделок и иных действий в обход закона.

Проблемы обхода закона затрагивались еще древнеримскими юристами. Так, Ульпиан отмечал, что «обход закона присутствует, когда делается то, чего закон не желает, но прямо не запрещает; и как сказанное слово отличается от мысли, так и обход закона отличается от того, что совершено противозаконно» [1, С. 113], не признавая, таким образом, обход закона противоправным деянием.

Ученые-цивилисты Российской империи рассматривали обход закона как явление, при котором стороны стремятся достичь своих целей без нарушения законодательно установлен- ных требований, причем данное явление обусловлено прежде всего недостатками правового регулирования, а не злонамеренностью или недобросовестностью участников правоотношений [См.: 3, С. 86]. Следовательно, в случае обхода закона следовало говорить только о недостатках формулировок законодательных положений, позволяющих обходить их без каких-либо существенных затруднений, а не о недобросовестности лиц, использующих такие недостатки.

В законодательстве и доктрине гражданского права советского периода обход закона в целом рассматривался как противоправное явление. Так, статьей 30 Гражданского кодекса РСФСР от 31.10.1922 г. предусматривалось, что сделка, «совершенная с целью противной закону или в обход закона, а равно сделка, направленная к явному ущербу для государства», является недействительной. В связи с тем, что цель предоставляемой гражданам РСФСР правоспособности состояла в «развитии производственных сил» (статья 4 Гражданского кодекса РСФСР от 31.10.1922 г.), А.Я. Канторович делал вывод о том, что «каждое действие, каждая сделка в области оборота, которые прямо не содействуют развитию производительных сил, могут быть опорочены как осуществляемые в противоречии с социально-хозяйственным назначением прав, вытекающих из этих действий и сделок» [2, С. 24]. В Гражданском кодексе РСФСР 1964 г. сделки, совершенные в обход закона, не упоминались и не выделялись из общей категории противозаконных сделок.

В действующем Гражданском кодексе Российской Федерации (ГК РФ) термин «обход за- 
кона» изначально не предусматривался, но был закреплен в после внесения изменений в 2012 г. В соответствии с пунктом 1 статьи 10 ГК РФ: «Не допускаются осуществление гражданских прав исключительно с намерением причинить вред другому лицу, действия в обход закона с противоправной целью, а также иное заведомо недобросовестное осуществление гражданских прав (злоупотребление правом)». Из положений данной статьи следует, что противозаконными, недопустимыми могут признаваться только такие действия в обход закона, которые совершаются с противоправной целью, следовательно, можно сделать вывод о принципиальном изменении подхода к правовой оценке такого явления, как обход закона, и связанных с ним правовых последствий.

Из буквального толкования приведенного выше законодательного положения следует, что сделки или иные действия, совершаемые в обход закона, в настоящее время могут признаваться незаконными только в тех случаях, когда противоправной является цель, преследуемая при их совершении.

На основании обобщения существующих доктринальных подходов и судебной практики представляется возможным предложить следующее определение понятия «обход закона»: «Обход закона - действия субъектов гражданского права, совершаемые с намерением не выполнять установленные законодательством требования или не применять иные установленные законодательством положения без их непосредственного нарушения». Предлагаемое определение учитывает закрепленные в настоящее время в законодательстве положения, согласно которым обход закона не может во всех случаях рассматриваться в качестве противоправного деяния, так как для признания действий по обходу закона правонарушением требуется установление дополнительных обстоятельств, связанных с намерениями осуществляющих их лиц и последствиями совершения таких действий.

В зависимости от правовых последствий сделок или иных действий, связанных с обходом закона, возможно разделить их на несколько категорий: во-первых, совершаемые в обход закона действия, представляющие собой злоупотребление правом, способные причинить вред другим лицам или публичным интересам, во-вторых, действия, совершаемые в обход закона и представляющие собой злоупотребление правом, но не приводящие к причинению вреда другим лицам или публичным интересам, и в-третьих, действия, имеющие исключительно признаки совершения в обход закона при отсутствии злоупотребления правом. Наличие последней категории обусловлено упомянутыми выше пробелами или противоречиями в законодательстве, а также отсутствием в ряде случаев возможности для субъектов гражданского права удовлетворить свои законные интересы в установленном законодательством порядке.

В качестве примера действий, совершаемых в обход закона, но не приводящих к причинению вреда публичным интересам или третьим лицам, может быть приведена ситуация, в которой единственный наследник либо один из наследников с согласия остальных наследников получает денежные средства со счета наследодателя по доверенности, выданной при жизни наследодателя и утратившей силу после его смерти. В указанном случае нарушается формальный порядок получения таких денежных средств, предусматривающий длительный срок принятия наследства и длительный период оформления документов, но при этом наследники получают доступ к денежным средствам, которые впоследствии должны перейти в их собственность, без причинения вреда каким-либо третьим лицам.

Совершение сделки или иного действия в обход закона следует признавать правонарушением только в том случае, если соответствующие действия субъектов гражданского права представляют собой злоупотребление правом и приводят или могут привести к причинению вреда публичным интересам либо правам и охраняемым законом интересам третьих лиц.

Примером сделок, представляющих собой обход закона и подлежащих признанию недействительными, может служить, в частности, пролонгация без соблюдения установленных процедур договора аренды недвижимого имущества, находящегося в федеральной или муниципальной собственности. Так, пунктом 1 Постановления Пленума Высшего Арбитражного Суда Российской Федерации от 17.11.2011 № 73 «Об отдельных вопросах практики применения правил Гражданского кодекса Российской Федерации о договоре аренды»" разъяснено, что

\footnotetext{
* Постановление Пленума Высшего Арбитражного Суда Российской Федерации от 17.11.2011 № 73 «Об отдельных вопросах практики применения правил Гражданского кодекса Российской Федерации о договоре аренды».
} 
договор аренды в отношении государственного или муниципального имущества должен заключаться исключительно на основании проведенных торгов, в связи с чем ничтожной сделкой должна признаваться любая пролонгация такого договора на условиях, указанных в ранее заключенном договоре, без проведения аукциона или торгов в порядке, установленном законом.

Вместе с тем критерий противоправности целей при совершении обхода закона, используемый в пункте 1 статьи 10 Гражданского кодекса Российской Федерации в качестве условия признания правонарушением действий, осуществляемых в обход закона, как представляется, должен быть заменен совокупностью критериев злоупотребления правом и посягательства на публичные интересы или права третьих лиц. Использование критерия, связанного с наличием вреда или возможностью его причинения публичным интересам либо физическим или юридическим лицам, позволит закрепить в законодательстве объективное основание для оценки в качестве правонарушения действий субъектов гражданского права, связанных с обходом установленных законодательных требований.

В связи с этим необходимо внести изменения в абзац первый пункта 1 статьи 10 ГК РФ, изложив положения, относящиеся к правонарушению в форме обхода закона, по аналогии с определением ничтожной сделки в пункте 2 статьи 168 ГК РФ, в следующей редакции: «Не допускаются осуществление гражданских прав исключительно с намерением причинить вред другому лицу, действия в обход закона, представляющие собой злоупотребление правом и посягающие на публичные интересы либо права и охраняемые законом интересы третьих лиц, а также злоупотребление правом путем иного заведомо недобросовестного осуществления гражданских прав».

Следует признать, что источником злоупотребления правами, в том числе совершаемого в форме обхода закона, является, прежде всего, несовершенство ряда норм гражданского права, обусловленное юридико-техническим формализмом при толковании и применении действующих норм гражданского законодательства либо пороком самих норм, закрепляемых гражданским законодательством, являющимся основным источником злоупотреблений в форме обхода закона.
При всех преимуществах, предоставляемых формализмом современного гражданского законодательства, включая общеобязательный характер законодательных предписаний, логичное изложение правового материала и др., он также создает предпосылки для злоупотребления правом, для использования различного рода формальных юридических схем, связанных с обходом закона.

В частности, в случае обхода закона часто используются ссылки на положения статьи 421 ГК РФ, устанавливающей свободу договора. Причиной данного явления служат не пороки статьи 421 ГК РФ, а пороки воли субъектов гражданских правоотношений, которые используют ее положения для злоупотребления правом. Абстрактность положений указанной статьи используется недобросовестными субъектами - сторонами сделки для частного толкования положений законодательства, игнорирующего требования статьи 422 ГК РФ, согласно которым договор должен соответствовать обязательным для сторон правилам, установленным законом и иными правовыми актами (императивным нормам), действующим в момент его заключения.

Формальность и абстрактность правил поведения - это продиктованные объективной необходимостью характеристики развитой системы гражданского права. Связанная с ними возможность использования отдельных положений законодательства для обхода закона, в том числе для обхода устанавливаемых законодательством запретов и ограничений, является объективно обусловленной.

Наряду с формализмом права условия для осуществления действий в обход закона в ряде случаев возникают вследствие разного рода пороков правового регулирования, включая смысловые ошибки, неточности, пробелы, противоречия в законодательстве, создающие предпосылки для неверного толкования правовых норм. Преодоление их последствий может достигаться путем внесения изменений в законодательство, официальными толкованиями и развитием правоприменительной практики, а также применением положений статьи 10 ГК РФ, позволяющих отказывать в судебной защите в случаях злоупотребления правом.

Вместе с тем следует еще раз отметить, что стороны сделок зачастую осуществляют обход не только неправильно сформулированных норм гражданского законодательства, но и достаточ- 
но качественных норм. Правовая изощренность недобросовестных лиц позволяет им разрабатывать отдельные сделки или последовательности сделок с целью обхода установленных нормами права требований, причем совершаемые сделки могут не нарушать непосредственным образом императивные нормы права, однако их последовательная реализация приводит к обходу законодательно установленных положений.

Наиболее частыми причинами обхода закона, таким образом, является правовая неопределенность, создаваемая отсутствием специальных правовых норм при недостаточной точности или детализированности общих правовых норм, регулирующих соответствующие правовые отношения, что позволяет недобросовестным субъектам создавать видимость правомерности своих действий при их направленности на достижение незаконной цели.

Сделки, совершаемые в обход закона, не имеют характера притворности. Если для притворной сделки форма ее выражения полностью соответствует закону, прикрывая истинную волю сторон, то в сделках в обход закона стороны стремятся к достижению планируемого результата, обходя непосредственно предназначенные для использования правовые механизмы за счет использования других предоставляемых законодательством возможностей. Разумеется, гражданское законодательство не может предписывать субъектам гражданских правоотношений использование определенных правовых подходов с установлением запрета в отношении использования иных правовых возможностей, поскольку это привело бы к нарушению принципа диспозитивности гражданско-правового регулирования.

Буквальное толкование положений закона (принцип текстуализма) не способно обеспечить достаточный уровень превенции в отношении действий субъектов гражданского права по обходу закона, в том числе таких, при совершении которых последовательность законных сделок или иных осуществляемых субъектами действий может приводить к достижению незаконного результата. В связи с этим недостатки российского законодательного обеспечения прямого запрета «обхода закона» должны восполняться обобщением судебной практики в целях исключения возможности использования юридического формализма в качестве основания для обхода закона.
Действенные способы, позволяющие преодолевать последствия юридического формализма в случае злоупотребления правом со стороны участников гражданско-правовых отношений, имеются в англо-американском праве, в котором понятие «circumvention» (обход) практически идентично по смыслу понятию «fraud» (обман). Под последним подразумевается действие, с помощью которого одна сторона пытается с использованием заведомо ложной информации ввести в заблуждение другую сторону, избежать чего-либо посредством какой-либо хитрости $[5, \mathrm{p}$. 153-171]. В качестве обмана англо-американское право рассматривает также случаи совершения сделок, которые в российском праве рассматриваются в качестве притворных или мнимых.

Анализ показывает, что доктринальные различия в толковании термина «обхода закона» в российском праве и во многом аналогичных ему терминов «evasion of law» («уклонение от закона»), «circumvention of law» («обход закона») в праве США обусловлены различием правовых систем и применяемых правовых подходов.

Для российского права основой формирования законодательных норм является прежде всего принцип справедливости, в то время как право США исходит из необходимости учета экономической обоснованности, в связи с чем обход закона, рассматриваемый в российском праве как деяние, противоречащее принципу справедливости, не анализируется в качестве такового в американском гражданском праве, основным предназначением которого признается обеспечение экономического оборота с использованием любых правовых способов, допускаемых законодательством.

Известно, что экономическая целесообразность как основа оценки и принципиального подхода к положениям закона достаточно давно зарекомендовала себя в качестве действенного ориентира для правоприменительной деятельности в западных странах, в особенности в США. Американский подход к современному гражданскому и торговому праву сформирован исходя из положений доктрины экономического анализа права (economic analysis of law), а также доктрины процессуально-правовой недобросовестности (procedural unconscionability), и заключается в принципиально иных постулатах «обхода закона». Суть американского доктринального подхода к гражданскому и торговому праву сводится к тому, что если закон экономи- 
чески нецелесообразен, то его нужно отменить или истолковать иным образом либо скорректировать с помощью судебного прецедента.

Попытки оценки экономической целесообразности законодательных положений постепенно начинают проявляться в отечественном гражданском праве и его подотрасли - договорном праве. Разумеется, это не соответствует ни традициям отечественного правоведения, ни существующей нормативной основе гражданского права Российской Федерации. Формализация понятия «обход закона» в ГК РФ призвана в том числе нивелировать эффект воздействия американских правовых доктрин, активно воспринимаемых отечественным правопорядком и судебной практикой.

Российское гражданское право в своей основе имело и имеет иные категории, в том числе этические и нравственные, нежели прямая зависимость эффективности и востребованности закона от его экономической целесообразности. Положения российского гражданского права традиционно основываются на принципах справедливости, добросовестности, нравственности и разумности. По мнению Е.А. Суханова экономическая целесообразность как фактор оценки эффективности действующего закона должна иметь вторичный характер: «частноправовое регулирование должно основываться прежде всего на внеэкономических понятиях справедливости и нравственности и только потом учитывать экономические аспекты, поскольку даже в имущественном споре его стороны ждут от судьи справедливого решения конфликта, а не сокращения издержек» $[4$, С. 8].

Если проблемой российского гражданского законодательства в преодолении такого явления, как «обход закона», является свойственный странам континентальной правовой семьи формализм, то гражданское и торговое право США отличается чрезмерной абстрактностью формулировок. Так, в судебной практике важнейшее значение имеет доктрина соблюдения добросовестности, но при этом в законодательстве США нет описания критериев добросовестности, их определение также оставляется на усмотрение суда.

Несмотря на невозможность непосредственного использования американских правовых доктрин в российской судебной практике ввиду их прямого противоречия основам российского гражданского права, они могут использовать- ся в качестве основы для выработки отдельных компенсационных мер законодательного и судебного характера, подобных тем, что имеются в торговом и гражданском праве США: институт эстоппель (estoppel concept), доктрина материально-правовой недобросовестности (substantive unconscionability), доктрина гибридной или смешанной недобросовестности (hybrid unconscionability), поскольку система американских судебных доктрин, будучи гибкой в отношении толкования действий субъектов, эффективно защищает интересы участников сделок от обхода закона их контрагентами.

Так, например, суть эстоппеля состоит в утрате права на возражение, права ссылаться на определенные факты или оспаривать определенные обстоятельства при недобросовестном или противоречивом поведении. Сторона не может ввиду выбранной ей линии поведения ссылаться на свое право в ущерб другой стороне, которая имела законное основание полагаться на выбранную контрагентом линию поведения и действовала соответствующим образом. Институт эстоппеля благодаря своему механизму функционирования является достаточно эффективным средством в борьбе против злоупотребления правом, в том числе в форме обхода закона.

Во взаимосвязи с принципом добросовестности находится также доктрина «чистые руки» (clean hands), согласно которой решение может основываться на том, что линия поведения одной стороны противоречит совести при условии безупречности поведения другой стороны.

Доктринальное понятие договорной дисциплины в российском гражданском праве не предусматривает запрета на совершение контрагентом действий с целью избежать обязательных требований закона или исполнения обязательств по договору, и, следовательно, не устанавливает обязанности воздержаться от действий, представляющих обход закона. Принятый в США подход, основанный на положениях доктрины «встречного удовлетворения», предполагает запрет любых действий контрагента по договору, включая направленные на обход закона, если их совершение может привести к тому, что встречное удовлетворение не будет предоставлено в том объеме или на тех условиях, на которые рассчитывала другая сторона при заключении договора. Данный подход, как представляется, также в определенной мере 
может быть использован в судебном толковании в рамках дальнейшего развития правоприменительной практики.

Рост значения судебного усмотрения, предоставление Верховному Суду Российской Федерации права выработки толкований законодательных актов в определенных пределах для различных сложных ситуаций, с которыми приходится сталкиваться на практике, а также использование при этом отдельных выработанных в США доктрин, обязывающих стороны действовать добросовестно, не допускать обмана и злоупотребления правом, причиняющего вред другим лицам, способны создать, как представляется, все необходимые предпосылки для эффективной борьбы с таким явлением, как обход закона.

\section{Библиографический список}

1. Дигесты Юстиниана / Пер. с лат.; Отв. ред. Л.Л. Кофанов. Москва. 2004. T. IV. 784 с.

2. Канторович Я.А. Имущественные права граждан СССР по действующему законодательству. Ленинград. 1925.160 с.

3. Дормидонтов Г.Ф. Классификация явлений юридического быта, относимых к случаям применения фикций: Юридические фикции и презумпции. Ч. 1. Казань. 1895. 185 с.

4. Суханов Е.А. О частных и публичных интересах в развитии корпоративного права // Журнал российского права. 2013. № 1. С. 5-9.

5. Beatson Jack and Friedmann Daniel (eds.). Good Faith and Fault in Contract Law. Clarendon Pess. Oxford, 1995. 560 p. 